JOEAI (Journal of Education and Instruction)

Volume 2, Nomor 1, Juni 2019

e-ISSN : 2614-8617

p-ISSN : 2620-7346

DOI : https://doi.org/10.31539/joeai.v2i1.713

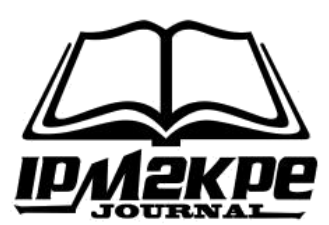

\title{
EFEKTIFITAS MEDIA FILM DAN STRATEGI PEMBELAJARAN SEMANTIC MAPPING DALAM MENINGKATKAN PENGUASAAN KOSAKATA BAHASA INGGRIS
}

\author{
Natalia Tri Astuti ${ }^{1}$, Fitri Senny Hapsari ${ }^{2}$ \\ Program Studi Teknik Informatika, Universitas Indraprasta PGRI ${ }^{1}$ \\ Program Studi Teknik Industri, Universitas Indraprasta PGRI ${ }^{2}$ \\ Natnatalia.lia@gmail.com ${ }^{1}$
}

\begin{abstract}
ABSTRAK
Penelitian ini bertujuan untuk mengetahui sejauh mana media film dan strategi pembelajaran semantic mapping dapat meningkatkan kosakata bahasa Inggris mahasiswa. Penelitian ini menggunakan pendekatan kualitatif dengan metode individual action research yang diawali dengan survey, observasi, wawancara dan tes dikelas. Penelitian dilaksanakan pada mahasiswa semester 1 jurusan informatika menggunakan metode penelitian kualitatif. Hasil penelitian, diperoleh hasil media film dan strategi pemetaan semantic, berpengaruh positif dan signifikan terhadap peningkatan kosakata bahasa Inggris mahasiswa. Simpulan, penggunaan film barat dan strategi pembelajaran semantic maping efektif untuk meningkatkan kosakata bahasa Inggris.
\end{abstract}

Kata Kunci: Media Film, Semantic Mapping, Kosakata, Bahasa Inggris

\begin{abstract}
This study aims to determine the extent to which film media and semantic mapping learning strategies can improve student English vocabulary. This study uses a qualitative approach with individual action research methods which begins with surveys, observations, interviews and tests in the class. The research was carried out on the first semester students majoring in informatics using qualitative research methods. The results of the study, obtained by the results of film media and semantic mapping strategies, had a positive and significant effect on the improvement of students' English vocabulary. Conclusions, use of western films and effective semantic maping learning strategies to improve English vocabulary.
\end{abstract}

Keywords: film media, semantic mapping, vocabulary, english 


\section{PENDAHULUAN}

Bahasa Inggris merupakan bahasa asing yang seharusnya bukan lagi menjadi hal yang baru dikalangan mahasiswa. Dalam perkembangan teknologi dimasa sekarang ini, dimana setiap teknologi kebanyakan menggunakan bahasa Inggris, membuat bahasa Inggris menjadi sangat akrab ditelinga. Demikian juga untuk kalangan mahasiswa yang dalam kesehariannya tidak terlepas dari teknologi. Teknologi yang selalu melekat dikalangan mahasiswa adalah telepon selular dan laptop. Dalam praktek nya, penggunaan telepon seluler dan laptop sebagian besar menggunakan bahasa Inggris. Hal ini tentu saja menuntut penggunanya untuk memahami bahasa Inggris.

Bahasa Inggris sebagai bahasa internasional dan masuk dalam kurikulum perguruan tinggi, memang bukanlah hal baru bagi mahasiswa. Akan tetapi, dalam prakteknya mahasiswa memiliki cukup banyak kendala dalam memahami bahasa Inggris. Kendala ini tentu dipengaruhi oleh banyak faktor, diantaranya; kurangnya rasa percaya diri dalam menggunakannya, kurang paham akan struktur bahasanya, tidak ada lawan berbicara ataupun perbendaharaan kata yang kurang (tidak memiliki kosakata yang cukup). Kosakata menjadi bagian yang sangat penting ketika seseorang ingin terampil berbahasa Inggris. Tanpa kosakata yang cukup, akan membuat belajar atau menggunakan bahasa Inggris menjadi sulit. Ditambah lagi, bahasa Inggris bukanlah ilmu pasti, sehingga ketika menerjemahkan bahasa Inggris ke dalam bahasa Indonesia proses penerjemahan selalu harus disesuaikan dengan konteks pembicaraan. Hal ini juga menjadi salah satu faktor yang membuat mahasiswa memiliki kendala yang cukup berarti.

Bahasa Inggris teknik, tentu berbeda dengan bahasa Inggris perkantoran atau perhotelan. Itu sebabnya kosakata sangat diperlukan dalam pembelajaran bahasa. Mengingat pentingnya meningkatkan kosakata bahasa Inggris mahasiswa, maka media pembelajaran dengan menggunakan film barat dipilih untuk membantu mahasiswa memahami lebih banyak kosakata. Film atau gambar bergerak adalah salah satu media audio visual yang bagus digunakan dalam pembelajaran yang dapat digunakan dalam kompetensi berbahasa secara terintegrasi dengan memanfaatkan bantuan teknologi (Ratminingsih, 2017).

Media pembelajaran yang tepat dan sesuai tentu dapat meningkatkan semangat dan bahkan hasil belajar mahasiswa. Media pembelajaran dengan strategi dan waktu yang tepat tentu akan memaksimalkan proses belajar mengajar dan juga hasilnya. Dalam pembelajaran, media dan strategi belajar mengajar merupakan bagian penting dari sebuah model pembelajaran. Model pembelajaran merupakan suatu perencanaan untuk merencanakan pembelajaran yang merupakan bingkai dari penerapan suatu pendekatan, metode, strategi dan teknik pembelajaran (Ikawati, 2018). Sementara, strategi pembelajaran adalah garis-garis besar haluan untuk bertindak dalam usaha mencapai sasaran yang telah ditentukan. Strategi dapat juga dikatakan sebagai pola-pola umum kegiatan guru, anak didik dalam perwujudan kegiatan belajar mengajar untuk mencapai tujuan 
yang telah digariskan (Hardini \& Puspitasari, 2012). Menurut Hamruni (2012) Pembelajaran merupakan suatu sistem instruksional yang mengacu pada seperangkat komponen yang saling bergantung satu sama lain untuk mencapai tujuan. Karena merupakan suatu system, maka pembelajaran memiliki suatu komponen. Komponen - komponen strategi pembelajaran, akan mempengaruhi jalannya pembelajaran. Semantic mapping adalah sebuah strategi pembelajaran yang memanfaatkan diagram atau grafik yang berisi kata-kata yang saling berhubungan antara satu dengan lainnya dalam satu topik atau tema tertentu, Ratminingsih (2017). Strategi ini menolong mahasiswa untuk menemukan beberapa kata yang memiliki keterkaitan antara satu dengan lainnya, sehingga dapat memperluas pemahaman mahasiswa tentang makna dari kata tersebut. Dalam pelaksanaannya, penggunaan strategi ini harus dilaksanakan dengan tepat dan menyenangkan, karena salah satu kelemahan nya adalah dapat menimbulkan kebosanan dan bahkan frustrasi. Hal ini dapat disebabkan karena keterbatasan kosakata dan sulit menentukan keterkaitan antar kata.

Kosakata dalam penggunaannya sangat diperlukan untuk mencapai keterampilan berbahasa. Menurut Hiebert \& Kamil (2005) kosakata adalah pengetahuan tentang kata dan makna kata yang membentuk bahasa. Seperti yang sudah diketahui oleh kebanyakan pembelajar bahasa Inggris, bahwa kata diklasifikasikan menjadi dua kategori utama, yaitu content words atau kata yang memiliki makna yang spesifik dan function words atau kata yang memiliki sedikit arti atau bahkan tidak berarti ketika kata tersebut terisolasi konteks, namun tetap memiliki gramatikal diantara kalimat sehingga membentuk makna.

Kosakata juga dapat dikatakan sebagai suatu kunci dalam pemahaman. Sebagai sebuah kunci, maka jika tidak dimiliki tentu saja tidak dapat masuk ke pemahaman yang dituju. Oleh sebab itu penelitian ini mengarah kepada peningkatan kosakata untuk mengetahui media dan strategi yang terbaik, menyenang kan dan juga efektif digunakan untuk pembelajaran kepada mahasiswa alam era teknologi ini.

\section{METODE PENELITIAN}

Penelitian ini berbentuk kualitatif dengan metode individual action research yang diawali dengan survey, observasi, wawancara dan tes dikelas. Evaluasi dilakukan kemudian, untuk mengetahui sejauh mana media film dan strategi pembelajaran semantic mapping secara bersama-sama dapat meningkatkan kosakata bahasa Inggris mahasiswa.

Penelitian ini bertujuan untuk memberi referensi baru dan membangun para praktisi bidang penelitian untuk berinovasi dan berkreasi dalam pengajaran yang dilakukan. Hal ini dapat dilakukan dengan memanfaatkan teknologi dengan segala perkembangannya yang sangat diminati oleh mahasiswa pada umumnya. Kedekatan hobi mahasiswa dengan media pembelajaran dan strategi yang digunakan ketika belajar, diharapkan mampu menyulut semangat mahasiswa 
dalam mempelajari hal yang selama ini dianggap sulit dan membosankan, khusunya kosakata bahasa Inggris. Karena pengajaran dengan media dan strategi yang dekat dengan pola hidup sehari-hari akan menjadi hal baru, tantangan, semangat dan motivasi tersendiri yang menyenangkan bagi mahasiswa.

Objek penelitian ini adalah mahasiswa informatika semester 1 tahun ajaran ganjil 2018/2019. Sampel yang digunakan sebanyak 60 mahasiswa dengan kriteria sangat menyukai film barat dan selalu menyaksikan film barat yang sedang ditayangkan.

Prosedur pelaksanaan penelitian dengan menonton film, diawali dengan melakukan persiapan film dan pelaratan yang akan digunakan, seperti laptop, speaker, LCD/ Proyektor untuk menayangkan film, selanjutnya mahasiswa menonton film per segmen dan mencatat kata asing yang baru atau jarang mereka dengar. Setelah mahasiswa memperoleh kata-kata dari menonton film , mahasiswa kemudian menggunakan catatannya untuk mencari arti dan penggunaannya dalam kalimat di kamus bahasa Inggris-Indonesia. Disaat yang sama dosen atau peneliti melakukan monitoring saat mahasswa sedang menulis dan memberikan arahan ketika mahasiwa menemui masalah. Selanjutnya mahasiwa masih diberikan kesempatan kedua untuk menonton film tersebut, dan memperbaiki draft yang salah dan diakhir sesi beberapa peserta didik diberikan kesempatan untuk membacakan tulisannya, sementara yang lain menyimak dan mengkoreksi jika ada kosakata penting yang dimasukkan atau ada kesalahan dalam tulisan tersebut (jika ada waktu).

Setelah pelaksanaan prosedur tersebut, maka dengan hasil "kata" baru yang ditemui, mahasiswa diminta memetakan "kata" tersebut dengan menggunakan strategi semantic mapping, adapun prosedur semantic mapping adalah mahasiswa menganalisis kosakata yang didapat dari film yang telah disaksikan, lalu menyusun kata-kata yang berhubungan kedalam bentuk peta ataupun grafik. Langkah selanjutnya mahasiswa akan memulainya dengan ide utama yang dituliskan dibagian tengah, kemudian menentukan cabang sebagai sub utama yang menarik bagi mereka, dan menentukan lagi cabang lainnya yang lebih kecil ataupun lebih luas sesuai dengan pemahaman mereka. Setiap mahasiswa menggunakan peta atau grafik untuk menambahkan informasi setiap saat dan mempresentasikan sebagai bahan masukan atau berbagi informasi dikelasnya.

Berikut ini merupakan salah satu contoh semantic mapping versi Keshavarz (2014), yang digunakan dalam pembelajaran dikelas informatika, setelah mahasiswa mendapatkan sebuah kata berdasarkan film yang mereka saksikan. 


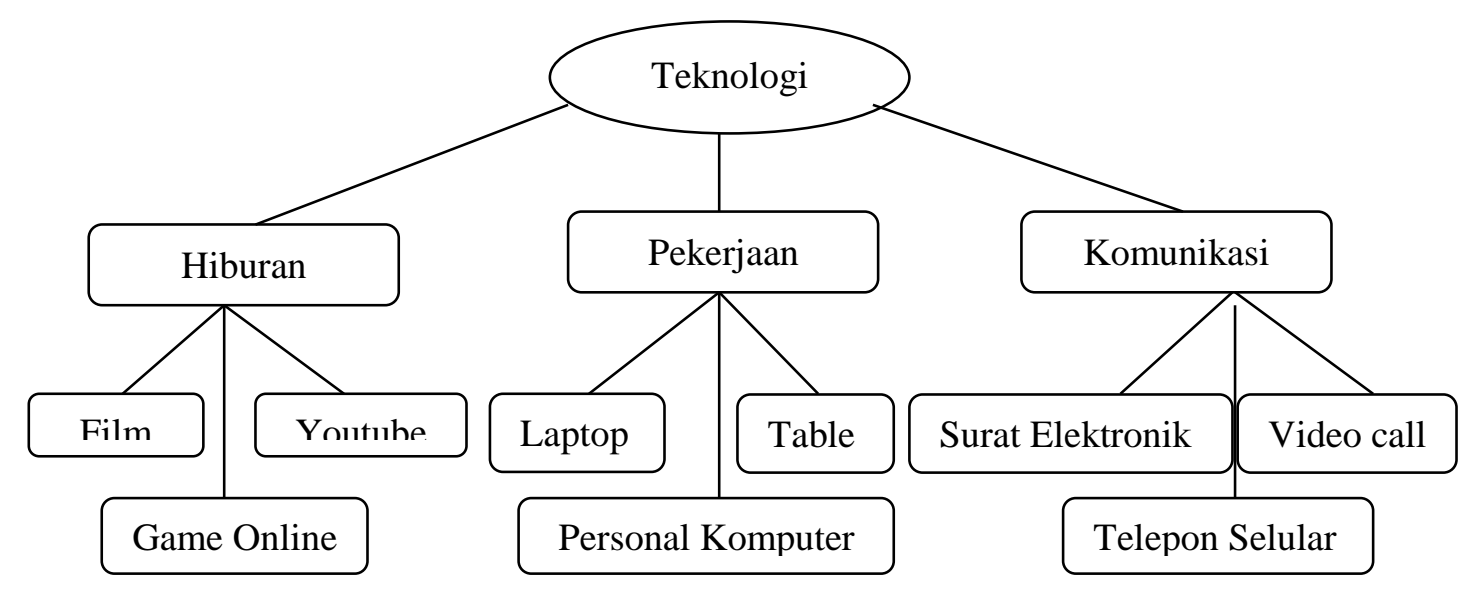

Gambar 1. Contoh Semantic Mapping

Sumber: Natalia, Fitri Senny

Setelah didapat semantic mapping seperti diatas, maka mahasiswa diminta mempresentasikan hasil nya untuk menginformasikan kepada yang lain juga mendapat koreksi ataupun masukan untuk semantic mapping yang lebih baik lagi. Pengumpulan data yang didapat kemudian berasal dari nilai akhir pemrolehan kosakata yang dikelompokkan sesuai dengan media dan strategi belajar yang digunakan selama proses pembelajaran berlangsung.

\section{HASIL DAN PEMBAHASAN}

Berdasarkan hasil penelitian yang dilakukan terhadap 60 mahasiswa, dengan bantuan SPSS 15.0, dan dibandingkan dengan hasil pretest yang sebelumnya dilakukan, maka didapat hasil peningkatan kosakata mahasiswa yang diajar dengan media film memiliki nilai rata-rata 79,0 dengan nilai tengah 82,0 dan nilai yang sering muncul 93,0, Sementara itu, peningkatan kosakata mahasiswa yang diajar dengan strategi semantic mapping memiliki nilai rata-rata 73,0 dengan nilai tengah 76,0 dan nilai yang sering muncul 81,0 , hal ini meningkat cukup signifikan jika dibandingkan dengan nilai pretest yang dilaksanakan sebelumnya.

Perhitungan juga dilakukan pada kelas yang diajar dengan media film dan strategi semantic mapping secara bersama-sama. Dalam kelompok ini diperoleh hasil nilai rata-rata 76,0 dengan nilai tengah 80,0 dan nilai yang sering muncul 80,0 . Setelah mendapatkan hasil perhitungan statistic tersebut, maka uji normalitas dilakukan untuk mengetahui apakah data berdistribusi normal atau tidak. Uji normalitas data dengan menggunakan analisis Kolmogorov Smirnov menunjukkan bahwa semua data berdistribusi normal. Karena nilai sig pada ketiga kelompok diatas masing-masing diperoleh 0,205, 0,522 dan 0,333. Ketiga nilai tersebut lebih besar dari 0,05. Maka kesimpulannya semua data berdistribusi normal. 
Uji homogenitas juga dilakukan untuk mengetahui apakah data bersifat homogeny. Dengan bantuan SPSS 15.0 dengan Levene's test, diperoleh nilai sig $0,120>0,05$ maka varian dikatakan homogeny.

Pengolahan data dilanjutkan dengan pengujian hipotesis. Uji hipotesis dilakukan untuk mengetahui apakah terdapat pengaruh ataupun interaksi dari media film dengan strategi semantic mapping. Perhitungan hipotesis dilakukan dengan ANAVA dua jalur dan diperoleh hasil sebagai berikut; pada kelompok media film diketahui nilai $f_{\text {hitung }}>f_{\text {table }}$ atau 7,438 > 3,148 dengan nilai sig 0,007 < 0,05 . Maka dapat disimpulkan terdapat peningkatan atau pengaruh pembelajaran dengan menggunakan media film terhadap peningkatan kosakata bahasa Inggris mahasiswa. Berikutnya pada kelompok strategi semantic mapping yang kemudian diketahui nilai $f_{\text {hitung }}>f_{\text {table }}$ atau 27,366 $>3,148$ dengan nilai signifikansi atau sig $0,000<0,05$. Maka dapat disimpulkan terdapat peningkatan atau pengaruh pembelajaran dengan menggunakan strategi semantic mapping terhadap peningkatan kosakata bahasa Inggris mahasiswa.

Interaksi antara media film dan strategi semantic mapping dinyatakan tidak ada, hal ini disebabkan oleh nilai $f_{\text {hitung }}>f_{\text {table }}$ atau 1,449 $>3,148$ dan nilai sig yang diperoleh $0,239>0,05$ yang berarti tidak terdapat interaksi antara media film dengan strategi semantic mapping.

Berdasarkan keseluruhan hasil perhitungan, dinyatakan kosakata bahasa Inggris mahasiswa meningkat dengan menggunakan media pembelajaran film maupun strategi semantic mapping, akan tetapi kedua hal ini tidak berinteraksi dengan cukup baik ketika digunakan secara bersama-sama. Ada cukup banyak faktor yang menyebabkan tidak adanya interaksi antara media film dengan strategi semantic mapping, diantaranya adalah keterbatasan waktu. Waktu yang sangat terbatas dan sudah banyak tersita saat menyaksikan film sebagai awal pembelajaran dinilai cukup menyita waktu sehingga kurang efektif pada bagian akhir pembelajaran.

\section{SIMPULAN}

Berdasarkan hasil penelitian yang telah dilakukan, maka dapat disimpulkan bahwa penggunaan film barat dan strategi pembelajaran semantic maping efektif untuk meningkatkan kosakata bahasa Inggris mahasiswa. Akan tetapi tidak terjadi interaksi diantara penggunaan media film barat dengan strategi semantic mapping. Hal ini dapat disebabkan oleh beberapa faktor, salah satu faktor yang paling mungkin adalah keterbatasan waktu pada setiap pertemuan. 


\section{DAFTAR PUSTAKA}

Hardini S \& Puspitasari, D. (2012). Strategi Pembelajaran Terpadu (Teori, Konsep dan Implementasi). Yogyakarta: Familia

Hamruni. (2012). Strategi Pembelajaran. Yogyakarta: Insan Mandani

Hiebert, E.H \& Kamil, M.L. (2005). Teaching and Learning Vocabulary: Bringing Research to Practice. London: Lawrence Erlbaum Associates

Keshavarz, M.H., Atai, M.R \& Mohammadi, S.M. (2014). The effect of Semantic Mapping Strategy Instruction on Vocabulary Learning of Intermediated EFL Students. Journal of Faculty of Letters anh Humanities, 49 (198), 149-176

Ratminingsih, N. (2017). Metode dan Strategi Pembelajaran Bahasa Inggris. Depok: Rajawali Press

Ikawati, H. D., Anwar, Z., \& Safitri, N. E. (2018). Efektifitas Pembelajaran Model Contextual Teaching dan Sains Teknologi Masyarakat terhadap Hasil Belajar Mahasiswa. Journal of Education and Instruction (JOEAI), 1(2), 59-65. doi:10.31539/joeai.v1i2.358 